\title{
ECONOMIC EFFICIENCY OF INVESTMENT IN GREENHOUSE VEGETABLE PRODUCTION WITHOUT HEATING
}

\author{
Radomir Bodiroga ${ }^{1}$, Zorica Sredojević ${ }^{2}$, Jonel Subic ${ }^{3}$ \\ *Corresponding author E-mail: radomir.bodiroga@gmail.com
}

A R T I C L E I N F O
Original Article
Received: 25 August 2018
Accepted: 24 September 2018
doi:10.5937/ekoPolj1804383B
UDC 338.435:[635.1/.8+631.544.4

Keywords:

Protected area, greenhouse, investments, vegetables, scenario analysis

JEL Q10, Q12

\begin{abstract}
A B S T R A C T
This paper analyzes the economic effectiveness of vegetable production in a protected area in terms and in a manner that is characteristic of the analyzed area (Bijeljina, Bosnia and Herzegovina). Dynamic methods for evaluating the economic feasibility of the investment were applied to two models of vegetables production in greenhouses. Models represent completely alternative investments, so the choice between them is based on the net present value. Economic justification under risk conditions was checked using the scenario analysis. The results of the survey indicate that the investments in both models are justified both in optimal and risky production conditions. The model that includes the production of two crops is economically more efficient than the production of one crop per year. The same model will take precedence also in risky production conditions, as indicated by the higher expected net present value and lower value of the coefficient of variation.
\end{abstract}

(C) 2018 EA. All rights reserved.

\section{Introduction}

Growing of vegetable products brings a number of benefits for both the agricultural producer and the community. Thus, in some countries of the world, vegetable production strongly affects the overall development of the economy, especially agriculture, but also food, chemical, pharmaceutical and other branches of industry, because for many countries exporting food, vegetables and processed vegetables, they represent very important products for acquiring foreign exchange income (Corovic et al., 2007). The data from the reports in the field of agriculture, food and rural development for Bosnia and Herzegovina (2016) show that vegetable lines with a share of $15 \%$ occupy a significant place in the total production of plants

1 Radomir Bodiroga, M. A., Ph. D. student, University of East Sarajevo, Faculty of Agriculture, Vuka Karadzica 30, 71123 East Sarajevo, B\&H, Phone: +387 55250122 , E-mail: radomir.bodiroga@gmail.com

2 Zorica Sredojević, Ph.D., Full professor, University in Belgrade, Faculty of Agriculture, Nemanjina 6, 11080,Zemun, Serbia, Phone:+381 1144132 97. E-mail: zokas@agrif.bg.ac.rs

3 Jonel Subić, Ph.D., Associate professor, Institute of Agricultural Economics, Volgina 15, 11060 Belgrade, Serbia, Phone: +381 116972848 E-mail: jonel_s@iep.bg.ac.rs 
in Bosnia and Herzegovina. Revenues from vegetable production per unit of capacity are multiple times higher than the corn and wheat incomes, thus achieving better financial effects and more stable economic sustainability of agricultural producers (Hadelan et al., 2015). In the world, there has been an increase in the development of horticultural product production in a protected area that is relatively safe for human life, primarily due to increased demand for fruit and vegetables as a result of the growth of the world's population as well as an increase in living standards (Kuswardhani et al., 2014). For the growing trend of cultivation of these agricultural products in the protected area, the importance of vegetable consumption in human nutrition, as well as the fact that adverse climatic conditions often determine its production in the open field, is also meritorious. Vegetable production in protected areas is of great biological and economic importance. It enables the supply of vegetables in the autumn, winter and spring periods, during which the annual cycle of production and consumption of vegetables closes with production during the summer (Djurovka et al., 2002). Thus the protected area enables the agricultural producer to place fresh products on the market in the offseason period, when the offer of these products is reduced, which positively affects their demand as well as the price of them. All these factors make the production of vegetables in a protected area very attractive for the agricultural producer.

Protected production is considered to be an intensive production system that requires relatively high investment in several aspects of production and marketing (Engindeniz, Tuzel, 2006). Depending on the complexity of the facility itself, the amount of invested stakes will vary, the justification of which must be adequately analyzed. In order for the production of vegetables in greenhouses to have maximum effect of invested funds per unit, managers of farms must use appropriate methods, techniques and models for the assessment of economic efficiency in agriculture (Subic et al., 2007). By applying dynamic methods for evaluating investments it is possible to determine the justification of investment in production in a protected space taking into account the time value of money. These methods require the estimation of future business results and their reduction to the present value.

Also, production in a protected area binds itself to a number of risks that need to be analyzed before the realization of the investment itself. Risk management is one of the most significant problems in the analysis of investments, because when making investment decision, future events can not be foreseen (Gogic, 2010). In risky operating conditions there is an exception between realized and projected business results due to the effects of many factors that can affect them. Therefore, when analyzing the justification of investment, it is also necessary to evaluate the justification of production in risky conditions using the generally accepted methods for this purpose.

\section{Materials and methods}

In this paper several methods have been used which, in accordance with the aim of the research, enable a thorough analysis of the justification of these investments.

The aim of this paper was to determine the economic feasibility of vegetable production in greenhouses in optimal and risky conditions, and also in the different manner of exploitation of the protected area. 
The aim also was to show the advantages of one of the two models used, based on the results obtained.

For the purpose of gathering information about the characteristics of the greenhouse production, primary sources of information for the analyzed area were used. The primary source is the results of the questionnaire covering vegetable producers in the protected area from the territory of Bijeljina. The survey was carried out in 2018. The companies that were the subject of research were selected by random sample method. The 37 family holdings were included into research. The sample includes farms in which the production of vegetables in greenhouses is the only or dominant source of income. By combining the questions of an open and closed type, trying to come all the available data were needed to continue the study. Data were collected on the structure of production, average yields, types of used greenhouses and similar. In order to determine the economic feasibility of the investment, investment models for greenhouse production have been created in various ways of using protected space. The model, as a simplified representation of the reality that is the subject of observation, sought to reflect the real situation in the analyzed area in terms of production technology and achieved production results. Production results on the present lines were determined using the calculation of net income (Direct Costing Method). The justification of investments in greenhouse production was analyzed taking into account the time value of money, and consequently, dynamic methods for evaluating investments were applied. Following dynamic methods were used: The net present value, the present value of net cash flow, internal rate of return and the payback period method.

The justification of investments in risky business conditions was analyzed using the scenario analysis method. The choice between investments that have complete alternatives was made depending on the net present value of the investment. The results are tabulated.

\section{Results and Discussions}

The area of the city of Bijeljina belongs to the regions with the largest production of vegetables in the Republic of Srpska (Bosnia and Herzegovina), both in the open air production and in the production in the greenhouses (Bodiroga, 2015). Based on the data obtained from the survey questionnaire, it has been established that there are several different design solutions in the surveyed area when it comes to protected areas. Glass greenhouses, as well as block types of greenhouses, were not present in the observed sample. The most common forms of protected areas are semi-high and high tunnels, while the rest are modern greenhouses without heating. Greenhouses with heating are solely used for the production of seedlings. One production line is realized on $89.25 \%$ of the area under greenhouses during the year. In this method of exploitation, tomatoes, cucumbers and the bell peppers are represented in greenhouses, and they are grown in greenhouses in the period from March to April until the first frosts occur (October-November). On the remaining 10.75\% of the area, two production lines are realized during the year. In this case, different combinations of crops are present, for example: cucumber-the capia type pepper, cucumber-cucumber, tomato-cucumber, cucumber-green beans and the like. 
Based on the data on realized net income, while taking into account the necessary assumptions, two models were created on the basis of which the analysis of economic feasibility of production under the given conditions was made:

- I Model - production of one line per year (cucumber);

- $\quad$ II Model - production of two lines per year (cucumber-green beans).

In the first model, production was selected in one line during the year, in order to determine the economic feasibility of the investment in conditions and in the way that production is most often taking place in the analyzed area. Cucumber production is planned during the entire exploitation period.

The second model determined the economic justification of the investment in a situation where two production lines are represented in the protected area. In this case, the cucumber has a shorter harvest period, less yields per unit area, and hence less revenues achieved. After the cucumber, green beans are grown, which also has similar defects in relation to the situation when it is grown as the only crop.

Both models used were created by taking into account the following assumptions:

- The family farm has $2000 \mathrm{~m}^{2}$ of protected area;

- Production is carried out without heating;

- Irrigation is a drop-drop system;

- The plastic sheet is changed every four years;

- Financing of the investment is carried out partly by own and partly by credit funds. The discount rate is therefore created as a weighted average between the opportunity costs and the interest rate on credit resources of $4.05 \%$;

- For agrotechnical operations, side-machine services are used, and paid work for them is included in net income calculations;

- Two working-age family members are engaged in production on the property;

- Gross salary for the work of family members is envisaged in the amount of $3700,00 €$ per year per member;

- Liquidation value of the investment object is determined on the basis of the depreciated value of the plastic sheet and the non-depreciated value of the construction which can be used approximately for 20 years;

- Earnings and issuances during the start-up and use of the investment arise at the end of the yea;

- With both models used, production is assumed in the same greenhouses and the same costs of raising the investment facility.

The costs of raising the investment facility consist of the costs of raising the greenhouse and the costs of installing the irrigation system. The models are supposed to use high tunnels. The costs of raising such an investment object are given in Table 1. 
Table 1. Costs of raising the investment object $\left(2000 \mathrm{~m}^{2}\right)$

\begin{tabular}{|l|l|}
\hline Type of expenses & Sum in $€$ \\
\hline Pipes & $6.043,21$ \\
\hline Plastic sheet for the greenhouse & $2.706,66$ \\
\hline Making a hole for the greenhouse & $1,350,00$ \\
\hline Painting and transport of greenhouse & $1,049,00$ \\
\hline Installation of greenhouse & 870,00 \\
\hline Other expenses & $2.142,95$ \\
\hline Total greenhouse & $14.161,82$ \\
\hline Irrigation system & 425,65 \\
\hline Total & $14.587,47$ \\
\hline
\end{tabular}

Source: Calculation of authors based on retail sales

The investment facility consists of five high tunnels of $400 \mathrm{~m}^{2}$. It can be seen from the table that the costs of procurement of greenhouse pipelines have the largest share in the total costs of the investment facility. The costs of the irrigation system can vary significantly depending on the location of the greenhouse and the type of irrigation system. The displayed costs include an irrigation system consisting of an electric motor pump and other perennial installation elements (alkaline pipes, couplings, semiconductors, taps and the like). This irrigation system is referred to by manufacturers as a system that requires not only the smallest investments, but also the least cost during exploitation.

The economic feasibility of investing in production in a protected area was determined by applying dynamic methods for evaluating investments. All dynamic methods are based on the assumption of the time value of money, according to which money available today does not have the same value as the money that will be available in the future.

The application of these methods is based on the determination of a series of cash receipts from the investment and a series of monetary issues made for the acquisition and use of an investment facility (Andric, 1998).

The projection of cash flows for the first model that determines the economic effectiveness of an investment in a protected space in which one line is produced annually is given in Table 2 .

Table 2. Projected net cash flow for model I

\begin{tabular}{|r|c|c|r|r|r|r|}
\hline Years & $\begin{array}{c}\text { Total } \\
\text { income } \\
(\boldsymbol{(})\end{array}$ & $\begin{array}{c}\text { Total } \\
\text { variable } \\
\text { costs } \\
(\boldsymbol{\epsilon})\end{array}$ & $\begin{array}{c}\text { Fees for the work of } \\
\text { family members } \\
(\boldsymbol{(})\end{array}$ & $\begin{array}{c}\text { Cost of } \\
\text { replacement } \\
\text { foil } \\
(\boldsymbol{(})\end{array}$ & $\begin{array}{c}\text { Total } \\
\text { expenditures } \\
(\boldsymbol{(})\end{array}$ & $\begin{array}{c}\text { Net cash } \\
\text { flow } \\
(\boldsymbol{\epsilon})\end{array}$ \\
\hline 1 & $14.358,97$ & $4.205,13$ & $7.400,00$ & 0,00 & $11.605,13$ & $2.753,84$ \\
\hline 2 & $14.358,97$ & $4.205,13$ & $7.400,00$ & 0,00 & $11.605,13$ & $2.753,84$ \\
\hline 3 & $14.358,97$ & $4.205,13$ & $7.400,00$ & 0,00 & $11.605,13$ & $2.753,84$ \\
\hline
\end{tabular}




\begin{tabular}{|r|r|r|r|r|r|r|}
\hline Years & $\begin{array}{c}\text { Total } \\
\text { income } \\
(\boldsymbol{\epsilon})\end{array}$ & $\begin{array}{c}\text { Total } \\
\text { variable } \\
\text { costs } \\
(\boldsymbol{(})\end{array}$ & $\begin{array}{c}\text { Fees for the work of } \\
\text { family members } \\
(\boldsymbol{(})\end{array}$ & $\begin{array}{c}\text { Cost of } \\
\text { replacement } \\
\text { foil } \\
(\boldsymbol{\epsilon})\end{array}$ & $\begin{array}{c}\text { Total } \\
\text { expenditures } \\
(\boldsymbol{(})\end{array}$ & $\begin{array}{c}\text { Net cash } \\
\text { flow } \\
(\boldsymbol{\epsilon})\end{array}$ \\
\hline 4 & $14.358,97$ & $4.205,13$ & $7.400,00$ & $2.706,66$ & $14.311,79$ & 47,18 \\
\hline 5 & $14.358,97$ & $4.205,13$ & $7.400,00$ & 0,00 & $11.605,13$ & $2.753,84$ \\
\hline 6 & $14.358,97$ & $4.205,13$ & $7.400,00$ & 0,00 & $11.605,13$ & $2.753,84$ \\
\hline 7 & $14.358,97$ & $4.205,13$ & $7.400,00$ & 0,00 & $11.605,13$ & $2.753,84$ \\
\hline 8 & $14.358,97$ & $4.205,13$ & $7.400,00$ & $2.706,66$ & $14.311,79$ & 47,18 \\
\hline 9 & $14.358,97$ & $4.205,13$ & $7.400,00$ & 0,00 & $11.605,13$ & $2.753,84$ \\
\hline 10 & $* 21.439,88$ & $4.205,13$ & $7.400,00$ & 0,00 & $11.605,13$ & $9.834,75$ \\
\hline
\end{tabular}

* Liquidation value of the investment included

Source: Calculation by author based on survey data

From Table 2 it can be noted that the net cash flow is positive throughout the analyzed period. The total variable costs consist of the costs of seeds, fertilizers, pesticides, fuels, as well as other materials necessary for the realization of the production process. The sum of the variable costs that arise in the production of cucumber, the compensation for the work of family members and the cost of replacement of the plastic cover make total expenses during the exploitation of the investment. The plastic cover was changed in the 4th and 8th years and that was when the net cash flow had the lowest value. Total incomes are generated entirely by selling cucumbers. The estimated liquidation value, which amounts to $7,080.91 €$, is included in the total incomes from the investment in the last observed year. The net present value, the present value of net cash flow, internal rate of return, as well as the payback period for the first model are given in Table 3.

Table 3. Value of indicators of economic efficiency of investment (model I)

\begin{tabular}{|l|l|}
\hline Indicators & Values \\
\hline Net present value $(€)$ & $8.174,46$ \\
\hline Internal rate of return $(\%)$ & $13 \%$ \\
\hline Payback period (years) & 8,19 \\
\hline Present value of net cash flow $(€)$ & $22.761,93$ \\
\hline
\end{tabular}

Source: Calculation by the author

The net present value of the investment shows the expected increase in investors' profits, which are created as a result of realization of a certain investment (Milić et all, 2005). The net present value of the investment has a value of $8,174.46 €$, it is greater than the limit value of 0 , which indicates that this is an investment that is economically justified. The same conclusion is obtained when the two other indicators used are also observed. Internal rate of return is the maximum interest rate that can be paid for the funds used in the project in order to recover the investment (Navyatha et all., 2015). The internal rate of return is higher than the minimum required rate of depreciation $(4.05 \%)$, while the payback period is shorter than the planned exploitation period. The present value of net cash flow 
gives an answer to the question of which is the largest amount of monetary assets that can be invested in an investment, and that it is economically acceptable under the given conditions and methods of financing (Milic et al., 2008). The upper limit of economic acceptability of investments in model $\mathrm{I}$ is $€ 22,761.93$.

The cash flow for the planned exploitation period for the second model used is given in Table 4.

Table 4. Projected net cash flow for model II

\begin{tabular}{|l|r|r|r|r|r|r|}
\hline Years & $\begin{array}{c}\text { Total income } \\
(\boldsymbol{\epsilon})\end{array}$ & $\begin{array}{c}\text { Total } \\
\text { variable costs } \\
(\boldsymbol{\epsilon})\end{array}$ & $\begin{array}{c}\text { Fees for } \\
\text { the work } \\
\text { of family } \\
\text { members } \\
(\boldsymbol{\epsilon})\end{array}$ & $\begin{array}{c}\text { Cost of } \\
\text { replacement } \\
\text { foil } \\
(\boldsymbol{\epsilon})\end{array}$ & $\begin{array}{c}\text { Total } \\
\text { expenditures } \\
(\boldsymbol{\epsilon})\end{array}$ & $\begin{array}{c}\text { Net cash } \\
\text { flow } \\
(\boldsymbol{\epsilon})\end{array}$ \\
\hline 1 & $15.743,59$ & $4.923,08$ & $7.400,00$ & 0,00 & $12.323,08$ & $3.420,51$ \\
\hline 2 & $15.743,59$ & $4.923,08$ & $7.400,00$ & 0,00 & $12.323,08$ & $3.420,51$ \\
\hline 3 & $15.743,59$ & $4.923,08$ & $7.400,00$ & 0,00 & $12.323,08$ & $3.420,51$ \\
\hline 4 & $15.743,59$ & $4.923,08$ & $7.400,00$ & $2.706,66$ & $15.029,74$ & 713,85 \\
\hline 5 & $15.743,59$ & $4.923,08$ & $7.400,00$ & 0,00 & $12.323,08$ & $3.420,51$ \\
\hline 6 & $15.743,59$ & $4.923,08$ & $7.400,00$ & 0,00 & $12.323,08$ & $3.420,51$ \\
\hline 7 & $15.743,59$ & $4.923,08$ & $7.400,00$ & 0,00 & $12.323,08$ & $3.420,51$ \\
\hline 8 & $15.743,59$ & $4.923,08$ & $7.400,00$ & $2.706,66$ & $15.029,74$ & 713,85 \\
\hline 9 & $15.743,59$ & $4.923,08$ & $7.400,00$ & 0,00 & $12.323,08$ & $3.420,51$ \\
\hline 10 & $* 22.824,50$ & $4.923,08$ & $7.400,00$ & 0,00 & $12.323,08$ & $10.501,42$ \\
\hline
\end{tabular}

Source: Calculation by author based on survey dana

In this model, net cash flow is also positive throughout the entire exploitation period. The used economic performance indicators are given in Table 5.

Table 5. Value of indicators of economic efficiency of investment (model II)

\begin{tabular}{|l|l|}
\hline Indicators & Values \\
\hline Net present value $(€)$ & $13.568,32$ \\
\hline Internal rate of return $(\%)$ & $18 \%$ \\
\hline Payback period (years) & 5,63 \\
\hline Present value of net cash flow $(€)$ & $28.155,79$ \\
\hline
\end{tabular}

Source: Calculation by the author

All indicators used provide information that an investment in a protected area where two crops would be cultivated during the year is also economically justified.

Given that Model I and Model II represent investments with the same amount of invested stakes and the same exploitation period (i.e. investments that are complete alternatives), the choice between them is the best accomplished by comparing the net present value. An investment is economically more efficient than its alternative investment if its net present value at a given calculated interest rate is higher (Andric et al., 2005). The investment in model II has a higher net present value and it can be concluded that it is more economically efficient compared to the investment in model I. 
The same conclusion can be achieved by comparing the internal rate of return that also has a higher value when investing in model II.

The use of dynamic methods imposes the need for a fairly accurate estimate of incomes and expenditures during the investment analysis period, which may be subject to increased uncertainty and error reporting during the predicting of the market situation (Szymszal et al., 2014). Decision making in terms of risk is a key component in the management of agriculture (Asci at al., 2014). Bearing in mind that agricultural production and consequently the production of greenhouses binds a number of risks that can lead to deviations between what is planned and achieved, often the economic justification of investments of this type is also checked under risk conditions by applying the generally accepted methods for this purpose. In analyzing the economic feasibility of the observed investments an scenario analysis was used in this paper. Scenario analysis includes key project risk factors (variables), its sensitivity to changes in key factors and the probability of changes (Brzakovic et all., 2016). It predicts three different scenarios (most likely, optimistic and pessimistic) when it comes to the value of key variables that affect economic effectiveness.

Three key factors (variables) whose changes in value are taken into account in the risk analysis are changes in the amount of invested stakes, changes in the level of expenditures for use of the investment, and changes in the amount of income during the exploitation period.

The most likely scenario is the assumption that the key variables will not change their values. This scenario will also have the highest probability of realization of $50 \%$.

The optimistic scenario predicts the improvement of the observed variables and will be the assumed increase in income during the exploitation period of 5\% in relation to the average achieved, while the assumption that the expenditures for the use of the investments as well as the amount of invested stakes is to be their decrease of $10 \%$ and $15 \%$.

The pessimistic scenario predicts deterioration of the key variables taken into consideration. Thus, a reduction income of $10 \%$ is expected, and the increase in the expenditures for use as well as invested stakes of $15 \%$ and $20 \%$ respectively.

The analysis scenario calculates the expected net present value of the investment in greenhouse production for both modeled models, as well as the standard deviation and coefficient of variation for the same, which can be used as additional indicators when choosing between the observed investments. The data are given in Tables 6 and 7 . 
Table 6. Scenario analysis of production in protected area (Model I)

\begin{tabular}{|c|c|c|c|}
\hline 1. Type of scenario & $\begin{array}{c}\text { Net present value } \\
(\mathrm{NPV})\end{array}$ & $\begin{array}{c}\text { Probability of realization } \\
\text { (P) }\end{array}$ & $\mathbf{N P V} * \mathbf{P}$ \\
\hline The most likely & $8.174,46$ & 0,50 & $4.087,23$ \\
\hline Pessimistic & $-20.134,43$ & 0,25 & $-5.033,61$ \\
\hline - Optimistic & $25.274,57$ & 0,25 & $6.318,64$ \\
\hline \multicolumn{3}{|c|}{ 2. Expected net present value } & $5.372,26$ \\
\hline \multicolumn{3}{|c|}{ 3. Standard deviation $\sigma$} & $16.297,22$ \\
\hline \multicolumn{3}{|c|}{ 4. Coefficient of variation $\mathrm{CV}$} & 3,03 \\
\hline
\end{tabular}

Source: Calculation by the author

Table 7. Scenario analysis of production in protected area (model II)

\begin{tabular}{|cl|c|c|c|}
\hline 1. & Type of scenario & Net present value (NPV) & Probability of realization (P) & NPV*P \\
\hline- & The most likely & $13.568,32$ & 0,50 & $6.784,16$ \\
- & Pessimistic & $-16.732,11$ & 0,25 & $-4.183,03$ \\
- & Optimistic & $31.809,44$ & 0,25 & $7.952,36$ \\
\hline 2. Expected net present value & & $10.553,49$ \\
\hline 3. & \multicolumn{3}{|l}{} & $17.424,82$ \\
\hline 4. & Coefficient of variation CV & 1,65 \\
\hline
\end{tabular}

Source: Calculation by the author

Based on the data in the tables, it can be seen that both investments in risky operating conditions are economically justified because the expected net present value is positive in both cases. Taking into account all three indicators used, the investment is more economical in model 2 , since it has a higher expected net present value and a smaller coefficient of variation compared to the first model observed.

\section{Conclusions}

Vegetable production in protected areas brings a number of advantages for the agricultural producer. However, this method of production demands and significant invested stakes whose justification is necessary to establish. Economic justification was carried out using dynamic methods for evaluating investments in two models showing the characteristic technology for the analyzed area. Individually, both investments are economically justified. Given that both investments have the same amount of invested stakes, the economically more attractive investment is in model II because it has a higher net present value. The results of the analysis scenario indicate that investments are economically justified in risky business conditions. The advantage of this criterion also has an investment in model II. This investment has the higher expected net present value, but also the lower value of the coefficient of variation. Based on the aforementioned, it can be concluded that the investment in high tunnels in which one crop is produced annually is economically justified. By cultivating two crops annually during the entire exploitation period, greater economic efficiency is achieved in both optimum and risky business conditions. 


\section{Conflict of interests}

The authors declare no conflict of interest.

\section{References}

1. Andrić, J., Vasiljević, Z., \& Sredojević, Z. (2005). Investments, basics of planning and analysis. Faculty of Agronomy, Belgrade-Zemun. [In Serbian: Andrić, J., Vasiljević, Z., Sredojević, Z. (2005): Investicije, osnove planiranja i analize. Poljoprivredni fakultet, Beograd-Zemun].

2. Andrić, J. (1998). Costs and calculations in agricultural production. Contemporary administration, s.s. Belgrade. [In Serbian: Андрић, J. (1998). Трошкови и калкулације у пољопривредној производњи. Савремена администрација д.д., Београд.

3. Asci, S., VanSickle, J.J., \& Cantliffe, J.D. (2014). Risk in Investment Decision Making and Greenhouse Tomato Production Expansion in Florida. International Food and Agribusiness Management Review, Vol. 17, Issue 4.

4. Bodiroga, R. (2015): Organizational-Economic Characteristics of Vegetable Production in Greenhouses in the Area of Bijeljina. Master thesis, Faculty of Agriculture, University of East Sarajevo. [In Serbian: Bodiroga, R. (2015): Organizaciono-ekonomska obilježja proizvodnje povrća u zaštićenom prostoru na području Bijeljine. Master rad, Poljoprivredni fakultet, Univerzitet $\mathrm{u}$ Istočnom Sarajevu].

5. Brzakovic, T., Brzakovic, A., \& Petrovic, J. (2016): Application of Scenario Analysis in the Investment Project Evaluation. Economics of Agriculture, Vol. 63, No 2, pp. 501-513.

6. Engindeniz, S., \& Tuzel, Y. (2006): Economic Analysis of Organic Greenhouse lettuce production in Turkey. Sci. Agric. (Piracicaba, Braz.), vol. 63, No.3, pp. 285-290.

7. Gogić, P. (2010). Economic Efficiency of Investments in Vineyard Production in Risky Circumstances. Economics of Agriculture, Vol. 57, No 3, pp. 393 410. [In Serbian: Гогић, П. (2010). Економска ефективност улагања у виноградарску производњу у условима ризика].

8. Hadelan, L., Grgić, I., Zrakić, M., \& Crnčan, A. (2015). Financial aspects of greenhouse vegetable production. Bulletin of plant protection, No 4, pp. 51-59. [In Croatian: Financijska ocjena proizvodnje povrća u zaštićenim prostorima. Glasnik zaštite bilja.

9. Kuswardhani, N., Soni, P., \& Shivakoti, G.P. (2014): Development Protected Cultivation in Horticulture Product: Feasibility Analysis in West Java Province. Advanced Science Engineering Information Technology, Vol. 4, No 5, pp. 66-70. 
10. Milić, D., Sredojević, Z., \& Jeločnik, M. (2008). Determination of Upper Limit for Investment in Cherry Plantation Establishment. Economics of Agriculture, Vol. 55, No 4, pp. 379-387. [In Serbian: Милић, Д., Средојевић, З., Јелочник, M. (2008). Утврђивање горње границе инвестирања у подизање засада вишње].

11. Milić, D., Bulatović, M., Kukić, Đ. (2005): Assesing the Economic Efficiency of Bulding Plantation Apple Fruits. Journal of Process Techniques and Eneretics in Agriculture, PTEP, Vol. 9, No 5, pp 118-120. [In Serbian: Milić, D., Bulatović, M., Kukić, Đ. (2005): Ocena ekonomske efektivnosti podizanja zasada jabučastog voća. Časopis za procesnu tehniku i energetiku u poljoprivredi].

12. Ministry of Foreign Trade and Economic Relations of Bosnia and Herzegovina (2017): Annual Report (2016) on Agriculture, Food and Rural Development for Bosnia and Herzegovina. [In Serbian: Ministarstvo vanjske trgovine i ekonomskih odnosa Bosne i Hercegovine (2017): Godišnji izvještaj (2016) iz oblasti poljoprivrede, ishrane i ruralnog razvoja za Bosnu i Hercegovinu.

13. Navyatha, N., Kumar Anesh, R., \& Rao Dayakar, B. (2015): Investment Analysis of Sorghum Products Developed by Premier ICAR Institution in Hyderabad. Research Journal of Agricultural Sciences, 6, pp. 1703-1706. ISSN: 0976-1675.

14. Szymszal, J., Lis, T., Gajdzik, B., \& Kliś, J. (2014): Analysis of the Possibility of Using Dynamic Methods for Assessment of Investment Projects in the Domestic Foundry Industry. Archives of Foundry Industry, Vol. 14, Issue 3, pp. 103-106.

15. Subić, J., Cecić, N., \& Kuzman, B. (2007). Economic Aspects of Vegetable Production in Greenhouses - Results of Mini Projects. Economics of Agriculture, Vol. 54, No 22, pp. 231-240. [In Serbian: Субић, Ј., Цецић, Н., Кузман, Б. (2007). Економски аспекти производње поврћа у заштићеном просторурезултати мини пројекта].

16. Đurovka, M., Lazić, B., \& Vujasinović,V. (2002).Microclimate conditions in greenhouses. Journal of Process Techniques and Eneretics in Agriculture, PTEP, Vol. 6, No 3-4, pp. 123-126. [In Serbian: Ђуровка, М., Лазић, Б., Вујасиновић, В. (2002). Микроклиматски услови у пластеницима. Часопис за процесну технику и енертетику у пољопривреди].

17. Đorović, M., Milanović, M., Stevanović, S., \& Lazić, V. (2007). The Global Vegetable Market. Economics of Agriculture, Vol. 54, No 2, pp. 109-130. [In Serbian: Ђоровић, М., Милановић, М., Стевановић, С., Лазић, В. (2007): Глобално тржиште поврћа]. 